University of Michigan Law School

University of Michigan Law School Scholarship Repository

Articles

Faculty Scholarship

1910

\title{
Limitation of a Carrier's Liability for Negligence
}

Edson R. Sunderland

University of Michigan Law School

Available at: https://repository.law.umich.edu/articles/1325

Follow this and additional works at: https://repository.law.umich.edu/articles

Part of the Torts Commons, and the Transportation Law Commons

\section{Recommended Citation}

Sunderland, Edson R. "Limitation of a Carrier's Liability for Negligence." Mich. L. Rev. 8 (1910): 222-4.

This Response or Comment is brought to you for free and open access by the Faculty Scholarship at University of Michigan Law School Scholarship Repository. It has been accepted for inclusion in Articles by an authorized administrator of University of Michigan Law School Scholarship Repository. For more information, please contact mlaw.repository@umich.edu. 
LIMIraTion of A CARRIER'S LIABHITY FOR NEGLIGENCE.-This is one of the subjects which never seems to be set at rest. In making contracts, shipper and carrier do not stand upon an equality. The shipper cannot exist without the 
aid of the carrier, but the carrier can easily forego the business of any particular shipper. Hence the ordinary rules of contract fail in many respects to meet the demands of the situation. To properly define the limitations necessary to be placed upon these rules is not an easy task.

While there are some cases to the contrary, it is almost universally held that a carrier cannot exempt himself by contract from liability for his own negligence. But many of the same courts which lay down this principle in its broadest form, at the same time hold that a carrier may by contract limit the amount of such liability. That is to say, he may by agreement avoid a portion of his liability but not all of it. This result is arrived at by holding that the parties to the contract of carriage may agree upon the valuation to be placed upon the goods carried, and since the freight rate is dependent upon the valuation, the agreement for a diminished valuation is supported by the consideration of a reduced rate. Such is the holding of the United States Supreme Court in the leading case of Hart v. Pennsylvania Railroad Company, 112 U. S. 33I.

In Winslow Brothers \& Company v. Atlantic Coast Line Railroad Company (Ig09), - N. C. - 65 S. E. 965, a car load of mules was shipped over defendant's line, and by negligence of the defendant, one of the mules, of the value of $\$ 20 \pi$, was killed. The bill of lading provided for an agreed valuation of $\$$ roo for each animal. Following the Hart case, the court held that the recovery was limited to the agreed valuation. There is, however, a vigorous and well-reasoned dissenting opinion by Chief Justice CLARK, who contends that the opinion of the majority practically abolishes the getieral rule that a carrier cannot by contract exempt himself from liability for negligence.

Under the facts of this case the agreement as to valuation was a mere form. No sane mán would voluntarily stipulate that an animal conceded to be worth \$20I was in fact worth \$100. No effort was made when the animals were shipped to ascertain their true value. The carrier merely used a printed form whereon it was stated that the shipper agreed that the value of each animal should be taken as \$100. Such a contract is obviously not primarily an agreement as to valuation, but it is intended by the railroad and in fact operates as a mere contractual limitation upon liability for negligence.

In the case under discussion the shipper was offered two rates, one of $\$ 200$ per car under the "agreed valuation," and one of $\$ 450$ per car without that provision, and yet.the court held that the shipper "has reaped the advantage of the special contract" and hence must abide by its terms. In other words, because the carrier consented to forego robbing the shipper, the latter has enjoyed a valuable consideration for his agreement to let the carrier off for half the loss caused by the carrier's negligence.

The case affords a good illustration of the academic nature of the rule in the Hart case. It will not work, for it permits, under the guise of an agreed valuation, the very thing which the courts which adopt that rule declare to be unlawful.

If the rule that carriers may not by contract exempt themselves from liability for their own negligence, is to be enforced, the strictly logical position taken by the Supreme Court of Alabama in the recent case of Southern 
Express Company v. Owens, $146 \mathrm{Ala}$. 412 , must be adopted. In that case the court squarely overruled an earlier decision-Louisville \& Nashville Railroad Company v. Sherrod, 84 Ala I78-which had held that "Limitations as to value do not come under the operation of the rule that a carrier cannot, by special contract, exempt himself from liability for the consequences of his own negligence, and ordinarily are not calculated to induce negligence. To the amount of the agreed valuation the carrier is responsible for loss occasioned by his neglect $* * *$ Such special contract is in the nature of an agreement to liquidate the damages, proportionately to the compensation received for the carriage and the responsibility of safely carrying and delivery." In overruling this decision the court said: "The agreement urged in the Sherrod case makes the degree of care requisite in the handling of goods depend, not on the nature of the thing to be carried-which ought to be the test of degree of care to be used by all persons or corporations pursuing the business of common carriess, even where a lawful contract limiting liability exists-but on the amount of compensation to be paid. $* * *$ - But would it not be a very dangerous rule which permits care to be measured by value? It would lead to a holding that the carrier owes but a slight degree of care when the thing to be carried is of small value intrinsically or by an agreed valuation, and the rule would be as fluctuating as is the value of the things carried. $* * *$ It seems to us that such contracts do induce a want of care, for the highest incentive to the exercise of due care rests in a consciousness that a failure in this respect will fix liability to make full compensation for any injury resulting from the cause. $* * *$ The rule of law being established, as we have seen it is, that the defendant company could not lawfully have contracted with the plaintiff that it would in no event be liable for any part of the value of the property lost or destroyed, can the limitation of its liability to $\$ 50$ be upheld in this court, if it should appear that its loss resulted from the negligence of the company, and that it was in fact worth 30 times that amount, as the court found it to be? We think not. To our minds it is clear that the two kinds of stipulation-that for total and that providing for partial, exemption from liability for the consequences of the carrier's negligence-stand upon the same ground and must be tested by the same principles."

E. R. S. 